HORTSCIENCE 26(3):310. 1991.

\title{
Nectarine Pox: A Disorder of Nectarine Fruit
}

\author{
Tara Auxt Baugher \\ West Virginia University Experiment Farm, Kearneysville, WV 25430
}

\author{
Stephen S.. Miller \\ Appalachian Fruit Research Station, U.S. Department of Agriculture, \\ Kearneysville, WV 25430
}

Additional index words. Prunus persica, nectarine pox, pox disorder

"Nectarine pox" is a disorder that reduces packout of commercially grown nectarines [Prunus persica (L.) Batsch Nucipersica (Schneid)]. Although accounts of the occurrence of nectarine pox are widespread across fruit growing regions and cultivars, we found no studies describing it in the literature. The disorder is characterized by superficial warty outgrowths (Fig. 1) and, in some years, may occur on $20 \%$ to $80 \%$ of the fruit in an orchard block. Suggested causal agents include low levels of B or a virus (S. Johnson, personal communication). The expression of the disorder follows a trend similar to that of cork spot on apple. Nectarine pox is not observed every year in an orchard; it tends to be most severe when the crop load is light, shoot growth is excessive, $\mathrm{N}, \mathrm{K}$, and/or $\mathrm{Mg}$ levels are excessive and $\mathrm{Ca}$ and/or B levels are low.

We have studied nectarine pox in West Virginia in a block of 'Firebrite' nectarines since 1984. Symptoms initially are observed $\approx 40$ days after anthesis, sometimes as a pale white or light-colored circular spot $\approx 0.5$ to $1.0 \mathrm{~mm}$ in diameter but more often as a slightly raised area similar in color and surface texture to the surrounding epidermal tissue. At this stage the

Received for publication 17 Apr. 1990. Approved for publication by the Director, West Virginia Agr. and For. Expt. Station as Scientific Article no. 2224. We thank Ronald Slonaker, David Leach, Joe Eldridge, Larry Crim, and Alan Biggs for their contributions toward describing the disorder. The cost of publishing this paper was defrayed in part by the payment of page charges. Under postal regulations, this paper therefore must be hereby marked advertisement solely to indicate this fact. protuberance may be $0.5 \mathrm{~mm}$ above the s\&rounding tissue, rounded or slightly pointed, and 1,0 to $2.0 \mathrm{~mm}$ in diameter at the base. Protuberances, or "warts", are occasionally clustered together, forming a larger irregular, rough, raised area, but generally are individually distinguished as singular outgrowths of the epidermis and subepidermal flesh tissue. As the fruit develops and enlarges, these warts expand and at harvest usually average 3 to 5 $\mathrm{mm}$ in diameter and 0.5 to 3 or $4 \mathrm{~mm}$ high (Fig. 1). The raised area generally is redder than the surrounding tissue. Paring through the raised tissue reveals flesh tissue that appears normal. While the warts of nectarine pox are not confined to any portion of the fruit's surface, we have often noted the first symptoms appearing between the equator and calyx end of the fruit. The symptoms are similar to beady wart (Blodgett, 1976) at harvest but in early stages are distinctly different. Nectarine pox and beady wart were both present in the 'Firebrite' block in 1989, and aphid feeding, the known cause of beady wart, resulted in sunken depressions of the epidermis, rather than eruptions, in initial stages. The symptoms of nectarine pox also are distinct from the cracking disorder of nectarine (Fogle and Faust, 1976), although it is likely that both abnormalities are influenced by the lack of pubescence.

The test orchard comprised nectarines at three locations on varying soil types. Nectarine pox had been observed in all blocks of fruit and on all cultivars $(1984,1987)$, including 'Crimson Gold', 'EarliBlaze', 'Fantasia', 'Firebrite', 'Flavortop', 'Summer Beaut', and 'Sunglo'. The disorder occurred most frequently and severely on 'Firebrite' in a block
Fig. 1. Characteristic warty outgrowths of nectarine pox.

in which tree growth had been excessive. The soil (Hagerstown silt loam) is highly fertile, and was a pasture before nectarines were established. Data collected for 6 years suggest several trends relating to the expression of the disorder (Table 1). Compared to standard tissue analysis values (Auxt et al., 1984; Ballinger et al., 1966) and to other blocks in the orchard, the $\mathrm{N}$ and $\mathrm{K}$ levels in the 'Firebrite' planting were excessive and $\mathrm{B}$ and $\mathrm{Ca}$ (fruit) were low. This nutritional imbalance, particularly high $\mathrm{N}\left(r^{2}=0.95, P>0.10\right)$, may predispose the trees to a high incidence of nectarine pox. In years when nectarine pox is most severe, other conditions that promote tree vigor are present. Increased incidence of nectarine pox also is associated with below normal yields, due to winter injury or early spring frosts, and abundant rainfall $\left(r^{2}=0.80, P \geq 0.05\right)$.

\section{Literature Cited}

Auxt, T. L., S. Singha, S.H. Blizzard. 1984. A survey of the nutritional status of West Virginia peach orchards. W.Va. Univ. Agr. For. Expt. Sta. Bul. 687.

Ballinger, W. E., H.K. Bell, and N.F. Childers. 1966 Peach nutrition, p. 276-390. In: N.F. Childers (cd.). Temperate to tropical fruit nutrition. Horticultural Pubs., New Brunswick, N.J.

Blodgett, E.C. 1976. Peach wart, p. 88-90. In: Virus diseases and noninfectious disorders of stone fruits in North America. U.S. Dept. Agr., Agr. Hdbk. 437.

Fogle, H.W. and M. Faust. 1976. Fruit growth and cracking in nectarines. J. Amer. Soc. Hort. Sci. 101:434438.

Table 1. Incidence of nectarine pox, yield, precipitation, and leaf and fruit nutrient levels in a block of 'Firebrite' nectarines during 1984-1989.

\begin{tabular}{|c|c|c|c|c|c|c|c|c|c|c|c|c|c|}
\hline \multirow[b]{2}{*}{ Year } & \multirow{2}{*}{$\begin{array}{c}\text { Nectarine } \\
\text { pox } \\
(\%)\end{array}$} & \multirow[b]{2}{*}{$\begin{array}{c}\text { Yield } \\
(\mathrm{kg} / \text { tree })\end{array}$} & \multirow{2}{*}{$\begin{array}{c}\text { June } \\
\text { rainfall } \\
(\mathrm{mm})\end{array}$} & \multicolumn{5}{|c|}{ Leaf nutrient levels } & \multicolumn{5}{|c|}{ Fruit (flesh) nutrient levels } \\
\hline & & & & $\begin{array}{c}\mathrm{N} \\
(\%)\end{array}$ & $\begin{array}{c}\mathrm{K} \\
(\%)\end{array}$ & $\begin{array}{l}\mathrm{Mg} \\
(\%)\end{array}$ & $\begin{array}{c}\mathrm{B} \\
(\mathrm{ppm})\end{array}$ & $\begin{array}{c}\mathrm{Ca} \\
(\%) \\
\end{array}$ & $\begin{array}{c}N \\
(\%)\end{array}$ & $\begin{array}{c}\mathrm{K} \\
(\%)\end{array}$ & $\begin{array}{l}\mathrm{Mg} \\
(\%)\end{array}$ & $\begin{array}{c}\mathrm{B} \\
\text { (ppm) }\end{array}$ & $\begin{array}{c}\mathrm{Ca} \\
(\%)\end{array}$ \\
\hline$\overline{1984}$ & $\begin{array}{ll}1 & 15 \\
& 15\end{array}$ & 43 & 47 & 3.84 & 2.59 & 0.36 & 25 & 1.68 & $\ldots$ & $\cdots$ & $\ldots$ & $\ldots$ & $\cdots$ \\
\hline 1985 & $\ldots 2$ & 0 & 71 & --. & -.. & $\ldots$ & -. & -.. & $\cdots$ & --- & -- & $\cdots$ & $\cdots$ \\
\hline 1986 & 5 & 90 & 35 & 3.44 & 2.52 & 0.47 & 25 & 2.48 & --- & $\ldots$ & --- & --- & --. \\
\hline 1987 & 80 & 62 & 102 & 3.91 & 3.18 & 0.53 & 34 & 2.29 & 1.43 & 1.83 & 0.54 & 11.4 & 0.26 \\
\hline 1988 & 3 & 79 & 27 & 3.84 & 2.94 & 0.63 & 36 & 2.64 & 1.06 & 1.75 & 0.54 & 13.4 & 0.27 \\
\hline 1989 & 12 & 54 & 70 & 3.90 & 3.13 & 0.45 & 32 & 1.82 & 1.01 & 1.62 & 0.65 & 18.7 & 0.30 \\
\hline$r^{2 y}$ & & 0.06 & $0.80^{* *}$ & 0.17 & 0.31 & 0.01 & 0.11 & 0.00 & $0.95^{*}$ & 0.52 & 0.16 & 0.40 & 0.38 \\
\hline
\end{tabular}

${ }^{2}$ Dashed line $=$ no data available.

${ }^{y}$ Coefficients of determination derived from regression of each of 12 predictors on percentage of fruit with nectarine pox.

${ }^{*, * *}$ Significant at $P=0.10$ or 0.05 , respectively. 